\title{
リン酸塩結合材を用いたパッチング耐火物の 作業性（可塑性）の低下機構
}

\author{
崎田真 一* 山本祐 一** 難 波徳 郎** \\ 三 浦 嘉 也吕* 林徹 浩**** 山口明 良 ${ }^{* * * * *}$
}

\section{Hardening Mechanism of Refractory Patching Materials with Phosphate Binder}

\author{
by
Shinichi SAKIdA *, Yuichi Yamamoto ${ }^{* *}$, Tokuro Nanba ${ }^{* *}$, Yoshinari MiurA ${ }^{* * *}$, Tetsuhiro HAYASHI ${ }^{* * * *}$ and Akira YAMAGUCHI ${ }^{* * * * *}$

\begin{abstract}
The hardening mechanism of refractory patching materials with a phosphate binder was investigated by means of ${ }^{31} \mathrm{P}$ static and magic angle spinning (MAS) nuclear magnetic resonance (NMR) spectroscopy. Ten refractory patching materials were made of refractory powders of $\mathrm{SiO}_{2}$ and fused alumina and five mixed solutions of phosphoric acid and aluminum biphosphate as phosphate binders. ${ }^{31} \mathrm{P}$ static and MAS NMR spectra were measured of five phosphate binders and twenty soft and hard refractory patching materials, respectively, to reveal the local structure around $\mathrm{P}$ atoms. The ${ }^{31} \mathrm{P}$ static and MAS NMR spectra revealed that $\mathrm{PO}_{4}$ tetrahedra in the phosphate binders have no $\mathrm{P}-\mathrm{O}-\mathrm{P}$ linkage between $\mathrm{PO}_{4}$ tetrahedra and that as the patching materials become hard, the ratio of $\mathrm{PO}_{4}$ tetrahedra with bridging oxygens increases, respectively. This result suggests that the hardening of the patching materials is caused by the condensation of the phosphate binder. But the ratio of $\mathrm{PO}_{4}$ tetrahedra with bridging oxygens was not enough to form the network by $\mathrm{P}-\mathrm{O}-\mathrm{P}$ linkage between $\mathrm{PO}_{4}$ tetrahedra. On the basis of these results, the hardening mechanism of refractory patching materials with a phosphate binder is proposed.
\end{abstract}

Key words : Refractory patching material, Phosphate binder, $\mathrm{SiO}_{2}$, Fused alumina, ${ }^{31} \mathrm{P}$ MAS NMR spectroscopy, Local structure, Hardening mechanism

\section{1 緒言}

大量生産，大量消費，大量廃棄の仕組みの中で，狭い 国土での高効率な土地活用打よび，最終処分場の延命化 が求められている日本にとって，一般廃棄物の社会的コ ンセンサスを得ている処理方式は「焼却し，埋め立てる」 方法である。日本の一般廃棄物の量は，年間約 5000 万 トンであり，そのうち $80 \%$ 弱を焼却に頼っている.1

焼却処理に使用される焼却炉の材料としては大きく分 けて，耐火レンガなどの定形耐火物と，キャスタブル材， プラスチック材などの不定形耐火物の二種類がある。不 定形耐火物は「粒状または練土状の耐火物」と JIS で定 義されて打り，耐スポーリング性（耐火物の亀裂や剥離 による損傷への而性）・気密性・低熱伝導性・緊急修理 などへの適応性，複雑異型で多種少量の煉瓦使用の場合 の置きかえ，損傷の激しい部分への熱間補修による炉の 延命など優れた機能を持つ.

パッチング材は，プラスチック材に属する柔らかい練 り土状の不定形耐火物であり, 耐火性の高い原料とバイ
ンダー（結合材）とを水で練り合わせて作製する．現在， ダイオキシン対策用高温溶融炉など高温溶解型産業で使 用される炉の補修材として主に使われている。中でも， リン酸塩系のバインダーを用いたパッチング材は，耐火 粘土を結合材とした材料に比べて冷間・熱間での強度に 優れ，耐摩耗性に優れている。また，冷間・熱間で既存 炬壁への吸着性が良いなどの特徴があるので広く利用さ れている.2) 4)

しかし製造後，密封保存しても時間が経過するにつれ て作業性（可塑性）の低下により硬化する性質がある。 しかも，硬化速度が比較的速いため長期間の保存には耐 えられないのが現状である。硬化すると作業性が非常に 悪くなるのみならず，製造段階より数倍硬くなり使用困 難になる場合すらある。従って，硬化速度を今まで以上 に抑制することにより長期間保存を可能にするような硬 化速度の制御技術の確立が現在必要とされている。

そこで本研究では硬化速度の制御の前段階として，ま ずリン酸塩結合材を用いたパッチング材中のリン原子の

\footnotetext{
$\dagger$ 原稿受理 平成 17 年 10 月 5 日 Received Oct. 5, 2005

* 岡山大学保健環境センター ₹700-8530 岡山市津島中, Health and Environment Center, Okayama Univ., Tsushima-Naka, Okayama, 700-8530

** 岡山大学環境理工学部環境物質工学科 †700-8530 岡山市津島中, Dept. of Environmental Chemistry and Materials, Faculty of Environmental Sci. and Tech., Okayama Univ., Tsushima-Naka, Okayama, 700-8530

*** 正 会 員 岡山大学環境理工学部環境物質工学科 ₹700-8530 岡山市津島中, Dept. of Environmental Chemistry and Materials, Faculty of Environmental Sci. and Tech., Okayama Univ., Tsushima-Naka, Okayama, 700-8530

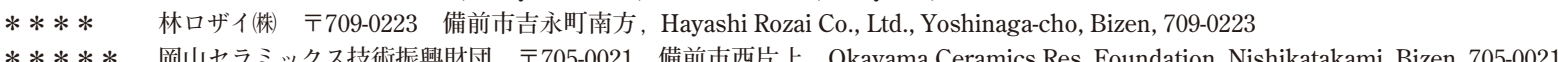


局所構造を ${ }^{31} \mathrm{P}$ マジック角回転 (MAS) 核磁気共鳴 (NMR) 分光法を用いてパッチング材の作業性（可塑性）の低下 機構の解明を試みた。

\section{$2 \cdot 1$ パッチング材の作製}

\section{2 実 験 方 法}

リン酸塩結合材を用いたパッチング材の耐火性の原料 には，電融アルミナ，ムライト，ベントナイト，焼ロー 石，バン土頁岩などがあり，いずれも主成分は $\mathrm{SiO}_{2}$ と $\mathrm{Al}_{2} \mathrm{O}_{3}$ (アルミナ）である.5), 6) そこで今回は代表的な原料 の主成分である $\mathrm{SiO}_{2}$ と $\mathrm{Al}_{2} \mathrm{O}_{3}$ として $\mathrm{SiO}_{2}$ 試薬 (quartz) および電融アルミナ粉末をそれぞれ原料として使用した。

バインダーにはリン酸 $75 \%$ 水溶液と重リン酸アルミニ ウム $50 \%$ 水溶液の混合溶液を選んだ。その混合割合をリ ン酸 100，75，50，25，0vol\% とした 5 種類の溶液をバ インダーとして使用した。

パッチング材は，各原料粉末 $3 \mathrm{~g}$ に各混合割合のバイ ンダーを加えて混合，混練することにより作製した。 バ インダーの使用量は $\mathrm{SiO}_{2}$ で $1.5 \mathrm{ml}$, 電融アルミナで 0.5 $\mathrm{ml}$ であった。 パッチング材の作業性（可塑性）の低下の 原因として(1) 骨材, 骨材中にある石灰, マグネシア, アルカリなどの不純物との反応，(2) 用水の揮散による 可塑性の変化, が挙げられる.3), 4) しかし, 本研究で用い た $\mathrm{SiO}_{2}$ 試薬は純度 $99.9 \%$, 電融アルミナは白色でいずれ も高純度なので, 6)不純物の影響は無視できると考えた。 ビニール袋で密封されたパッチング材は, 硬化するとき に袋の内側に水滴がつく現象が見られた。この事から， パッチング材の硬化はパッチング材から水分が蒸発する事 が原因と考え, $110^{\circ} \mathrm{C}$ 乾燥機で完全に硬化させたパッチ ング材を作製した。

\section{$2 \cdot 2{ }^{31} \mathbf{P}$ 静止および MAS NMR 測定}

パッチング材中のリン原子周辺の局所構造を明らかに するために，5種類のバインダー溶液，作製後約 $12 \mathrm{~h}$ 経 過した練り土状の柔らかいパッチング材と $110^{\circ} \mathrm{C}$ の乾燥機 でパッチング材を完全に硬化させた後粉末状にした試料 について， ${ }^{31} \mathrm{P}$ 静止および MAS NMR 測定を行った。測 定装置はV Varian UNITY INOVA 300 MAS FT-NMR スペク トロメーター (7.05T) を使用した。測定条件は共鳴周波 数 $121.425 \mathrm{MHz}$, MAS NMR 測定時の回転速度は 5500 $6500 \mathrm{~Hz}$ とし, 標準試料として $\mathrm{NH}_{4} \mathrm{H}_{2} \mathrm{PO}_{4}$ を用いた. パルス 幅 $2.0 \mu \mathrm{s}$, 繰り返し時間 $2.0 \mathrm{~s}$, バインダー液は 80 回, パッ チング材は 400 ～ 1000 回の積算回数で測定を行った.

柔らかい練り土状のパッチング材は, MAS NMR 測定 時, 高速回転による遠心力のため, 試料中の水分がいく らか失われた状態になっていた。しかし，完全に乾燥し たわけではなく, 試料の中に水分がいくらか残っている 状態であった。 また，作製直後ほどではないが，練り土 状の柔らかさを保っていた。よって今回得られたスぺク トルは，作製直後の水分が豊富な時の状態を反映してい るわけではないが, 水分を含んだ柔らかい練り土状のパッ チング材の状態を反映しているといえる.

\section{3 結 果 と 考 察}

\section{$3 \cdot 1$ リン酸 $\left(\mathrm{H}_{3} \mathrm{PO}_{4}\right)$ および重リン酸アルミニウム} $\left(\mathrm{Al}\left(\mathrm{H}_{2} \mathrm{PO}_{4}\right)_{3}\right)$ 中のリン原子の基本構造

リン酸および重リン酸アルミニウム中のリン原子は酸 素四配位であり， $\mathrm{PO}_{4}$ 四面体から成っている。一般的に $\mathrm{PO}_{4}$ 四面体の基本構造は架橋酸素の数によって分類し, 架橋酸素数 $\mathrm{n}$ の基本構造を $\mathrm{Q}_{\mathrm{n}}$ と表記する. リン酸中の $\mathrm{PO}_{4}$ 四面体は, リン原子と結合した 4 つの酸素のうち 1 つ が二重結合酸素，残り 3 つが一重結合酸素でさらに水素 と結合した $\mathrm{O}=\mathrm{P}(-\mathrm{O}-\mathrm{H})_{3}$ という構造をしており，この四 面体は脱水縮合により-P-O-P-連結の形成が可能である. 従って, リン酸中の $\mathrm{PO}_{4}$ 四面体の基本構造は架橋酸素の 数によって, $\mathrm{Q}_{0}, \mathrm{Q}_{1}, \mathrm{Q}_{2}, \mathrm{Q}_{3}$ の 4 種類に分類できる. Fig. 1 (a) にその基本構造 $\mathrm{Q}_{0} \sim \mathrm{Q}_{3}$ を示す. 図中の BO は 2 個のリン原子と結合し-P-O-P-連結を作る架橋酸素で ある。他方， NBO は1個のリン原子とのみ結合し-P-O$\mathrm{P}$ 一連結は作らない非架橋酸素を示している。 DBO は二重 結合酸素である. $\mathrm{PO}_{4}$ 四面体によるネットワーク形成が 可能な構造は, 架橋酸素数の多い $\mathrm{Q}_{2}, \mathrm{Q}_{3}$ である.

重リン酸アルミニウム結晶 ${ }^{7)}$ は $\mathrm{PO}_{4}$ 四面体と $\mathrm{AlO}_{6}$ 八 面体とが交互に頂点共有で連結することで直鎖を形成し， その直鎖間は $\mathrm{P}-\mathrm{OH}$ 基間の水素結合で互いに連結した構 造をしている。この結晶は非常に吸湿性が強いため，大 気中では普通水を含んだ形で存在する。従って, 重リン 酸アルミニウム中の $\mathrm{PO}_{4}$ 四面体は, $\mathrm{PO}_{4}$ 四面体の 4 つの 酸素のうち 2 つが別々の $\mathrm{AlO}_{6}$ 八面体と頂点共有して鎖 を作るのに使われる (Fig. 1 (b)). よって，脱水縮合によ り-P-O-P-連結形成可能な酸素は 2 つである。 また，こ の $\mathrm{PO}_{4}$ 四面体はリン酸の場合とは異なり二重結合がない ので，リン酸の $\mathrm{PO}_{4}$ 四面体とは異なる結合状態をしてい ると考えられる。そこで, リン酸の $\mathrm{PO}_{4}$ 四面体とは異な ることを示すために, 重リン酸アルミニウム中の $\mathrm{PO}_{4}$ 四 面体の基本構造を $\mathrm{Q}_{\mathrm{n}}$ 'と表記した。従って，重リン酸ア ルミニウム中の $\mathrm{PO}_{4}$ 四面体の基本構造は架橋酸素数によ って $\mathrm{Q}_{0}{ }^{\prime}, \mathrm{Q}_{1}{ }^{\prime}, \mathrm{Q}_{2}{ }^{\prime}$ の 3 種類に分類できる. Fig. 1 (b) に その基本構造 $\mathrm{Q}_{0}{ }^{\prime} \sim \mathrm{Q}_{2}{ }^{\prime}$ を示す。重リン酸アルミニウムの 場合, 元々 $\mathrm{PO}_{4}$ 四面体と $\mathrm{AlO}_{6}$ 八面体とから成る直鎖に よるネットワークがすでに形成されているが，架橋酸素 数が増大するにつれてより複雑に絡み合ったネットワー ク形成が可能となる.

(a) Phosphoric acid $\left(\mathrm{H}_{3} \mathrm{PO}_{4}\right)$

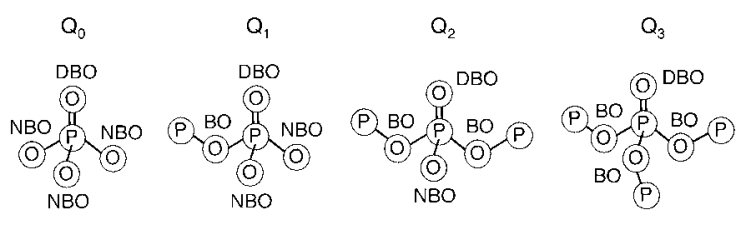

(b) Aluminum biphosphate $\left(\mathrm{A} \mid\left(\mathrm{H}_{2} \mathrm{PO}_{4}\right)_{3}\right)$

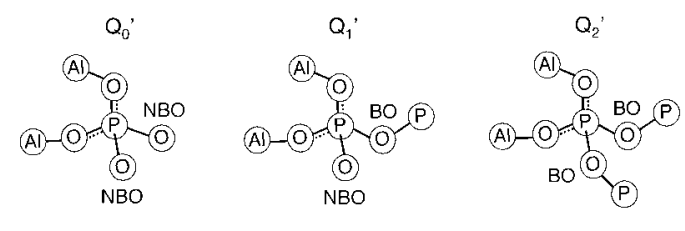

Fig. 1 Basic structures of $\mathrm{PO}_{4}$ tetrahedra in phosphoric acid $\left(\mathrm{H}_{3} \mathrm{PO}_{4}\right)$ (a) and aluminum biphosphate $\left(\mathrm{Al}\left(\mathrm{H}_{2} \mathrm{PO}_{4}\right)_{3}\right)(\mathrm{b})$. 


\section{$3 \cdot 2{ }^{31} \mathrm{P} \mathrm{NMR}$ における $\mathrm{PO}_{4}$ 四面体の基本構造と 等方性化学シフトとの関係}

Table 1 に $\mathrm{PO}_{4}$ 四面体の基本構造と等方性化学シフト $\delta$ $(\mathrm{ppm})$ との関係を示す. $\mathrm{Q}_{\mathrm{n}}(\mathrm{n}=0 \sim 3), \mathrm{Q}_{\mathrm{n}}{ }^{\prime}(\mathrm{n}=0 \sim 2)$ のいずれも架橋酸素数が増加するにつれて，等方性化学 シフト值は小さくなっている. $\mathrm{Q}_{\mathrm{n}}(\mathrm{n}=0 \sim 3)$ および $\mathrm{Q}_{0}$, と $\mathrm{Q}_{2}{ }^{\prime}$ 等方性化学シフト範囲についてはすでに明らか にされているが ${ }^{8) \sim 10)} \mathrm{Q}_{1}{ }^{\prime}$ 範囲については未だ明らかに されていない. しかし上で述べたように，架橋酸素数の増 加とともに等方性化学シフト值が小さくなる傾向がある ので, $\mathrm{Q}_{1}^{\prime}$ 範囲は $\mathrm{Q}_{0}{ }^{\prime}$ と $\mathrm{Q}_{2}{ }^{\prime}$ の間にくるものと考えられる. 従って, $\mathrm{Q}_{1}$ の範囲を-15〜-30ppm と考えて考察を行った. この関係に基づいて，本研究で測定した試料の ${ }^{31} \mathrm{P} \mathrm{NMR}$ スペクトルピークの帰属を行った。

\section{$3 \cdot 3$ バインダー溶液の ${ }^{31} \mathbf{P}$ 静止 NMR スペクトル}

Fig. 2 は， 5 種類のバインダー溶液の ${ }^{31} \mathrm{P}$ 静止 $\mathrm{NMR}$ スペクトルを示している. 四中の数值は等方性化学シフ 卜值を示している。一番上のスペクトルがリン酸 $75 \%$ 水 溶液のみのものであり，下にいくにつれて重リン酸アル ミニウム $50 \%$ 水溶液の割合が増大し，一番下が重リン酸 アルミニウム $50 \%$ 水溶液のみのスペクトルである。いず れもシャープなピークが得られており, 重リン酸アルミニ ウム溶液の割合が増大するにつれて，ピークが高磁場側 (右側) にシフトしていることが分かる.リン酸, 重リン酸 アルミニウム溶液の等方性化学シフト值は $0.1,-7.8 \mathrm{ppm}$ で あり，これらはそれぞれ $\mathrm{O}=\mathrm{P}(-\mathrm{O}-\mathrm{H})_{3},(\mathrm{Al}-\mathrm{O})_{2}-\mathrm{P}(-\mathrm{O}-\mathrm{H})_{2}$ 構造をしているので，それぞれ $\mathrm{Q}_{0}, \mathrm{Q}_{0}{ }^{\prime}$ 構造に帰属で きる。

混合溶液のピークはリン酸，重リン酸アルミニウム溶 液の間に出現している。このことは，バインダー溶液同 士の混合だけではリン酸塩間での脱水縮合は起こらない ことを示している，ピークの線幅は十分狭いので，混合 溶液のピークはリン酸, 重リン酸アルミニウムのそれぞ れのピークが合成されてできたピークではなく, リン酸, 重リン酸アルミニウムが液中で十分に混ざり合って一本 のシャープなピークになっていると考えられる.

Table 1 Isotropic chemical shift ranges of basic structures $\mathrm{Q}_{\mathrm{n}}$ and $\mathrm{Q}_{\mathrm{n}}$ of $\mathrm{PO}_{4}$ tetrahedra in phosphoric acid $\left(\mathrm{H}_{3} \mathrm{PO}_{4}\right)$ and aluminum biphosphate $\left(\mathrm{Al}\left(\mathrm{H}_{2} \mathrm{PO}_{4}\right)_{3}\right)$, respectively. Symbol $\mathrm{n}$ in $\mathrm{Q}_{\mathrm{n}}$ and $\mathrm{Q}_{\mathrm{n}}$ ' denotes the number of bridging oxygen.

\begin{tabular}{cc|cc}
\hline \multicolumn{2}{c|}{$\mathrm{H}_{3} \mathrm{PO}_{4}$} & \multicolumn{2}{c}{$\mathrm{Al}\left(\mathrm{H}_{2} \mathrm{PO}_{4}\right)_{3}$} \\
$\mathrm{Q}_{\mathbf{n}}$ & $\delta(\mathrm{ppm})$ & $\mathrm{Q}_{\mathbf{n}}{ }^{2}$ & $\delta / \mathrm{ppm}$ \\
\hline $\mathrm{Q}_{0}$ & $+14 \sim-6^{6)}$ & $\mathrm{Q}_{0}{ }^{\prime}$ & $-15^{7)}$ \\
$\mathrm{Q}_{1}$ & $4 \sim-22^{6)}$ & $\mathrm{Q}_{1}{ }^{\prime}$ & $-15 \sim-30^{*}$ \\
$\mathrm{Q}_{2}$ & $-16 \sim-27^{6)}$ & $\mathrm{Q}_{2}{ }^{\prime}$ & $-30 \sim-52^{7), 8)}$ \\
$\mathrm{Q}_{3}$ & $-32 \sim-46^{6)}$ & & \\
\hline
\end{tabular}

* Estimated range as the isotropic chemical shift range between $\mathrm{Q}_{0}{ }^{\prime}$ and $\mathrm{Q}_{2}{ }^{\prime}$. The isotropic chemical shift range of $\mathrm{Q}_{1}$ ' has not been reported so far.

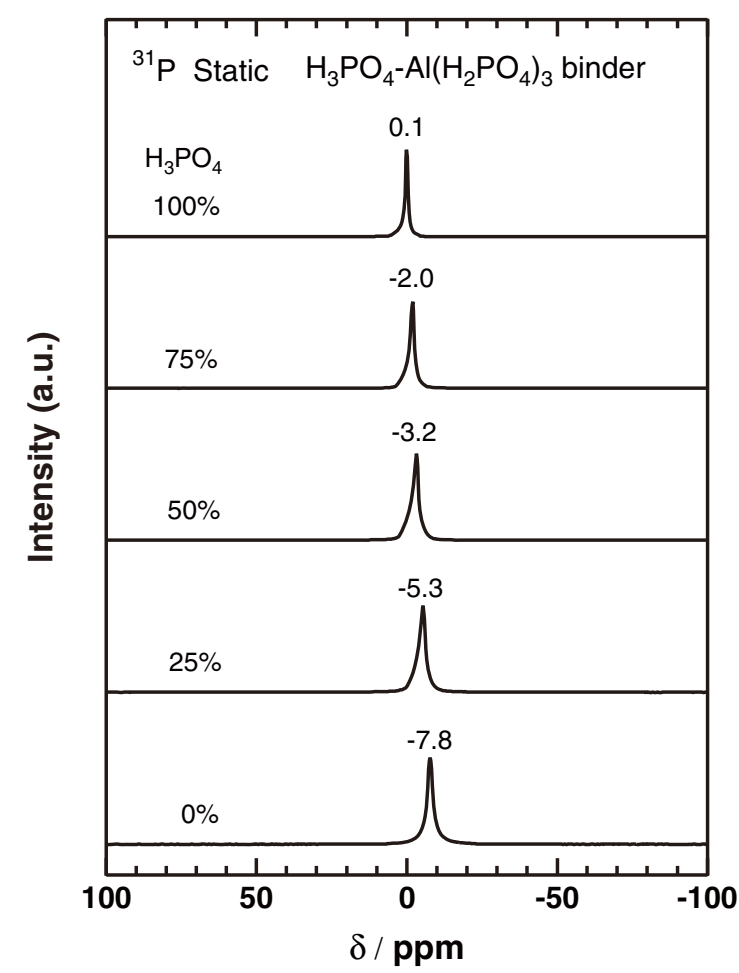

Fig. $2{ }^{31} \mathrm{P}$ static NMR spectra of five phosphate binders composed of mixed solutions of phosphoric acid and aluminum biphosphate.

\section{$3 \cdot 4$ パッチング材の ${ }^{31} \mathbf{P}$ MAS NMR スペクトル}

Fig. 3 は $\mathrm{SiO}_{2}$ 原料のパッチング材の ${ }^{31} \mathrm{P}$ MAS NMR ス ペクトルを示している。左図が柔らかい練り土状のパッ チング材, 右困が完全に硬化したパッチング材の ${ }^{31} \mathrm{P}$ MAS NMR スペクトルを示している. 図中の数值はピー ク位置，*印はスピニングサイドバンドを表している。一 番上のスペクトルがリン酸 $75 \%$ 水溶液のみのものであり, 下にいくにつれて重リン酸アルミニウム $50 \%$ 水溶液の割 合が増大し, 一番下が重リン酸アルミニウム $50 \%$ 水溶液 のみのスペクトルである. Table 1 に基づいて各ピーク の帰属を行った。 また, リン酸 $75,50,25 \mathrm{vol} \%$ のバイン ダー溶液の各ピークの帰属に関しては, Table 1 の他に 各ピークの強度比, バインダー溶液の体積比, リン酸 100，0vol\%でのピーク位置も考慮した。その結果得られ た各ピークに帰属できる $\mathrm{PO}_{4}$ 四面体の基本構造を図中に 示した。

左罒のピークは $0.1 〜-11.7 \mathrm{ppm}$ の範囲で現れており, Fig. 2 の等方性化学シフト值に近いことから, 水分をい くらか含む柔らかい練り土状のパッチング材中のリンは $\mathrm{Q}_{0}, \mathrm{Q}_{0}{ }^{\prime}$ 構造に帰属でき, リン酸塩間の縮合は起こって いないと考えられる。

右図では，リン酸を 50 〜 100vol\% 含むバインダーで $0 \mathrm{ppm}$ 付近の鋭いピークと-13ppm 付近の小さいピークが 現れた。リン酸を $25 \mathrm{vol} \%$ 含むバインダーでは, $-0.8 \mathrm{ppm}$ の鋭いピークの他に-15.8ppm と-31.1ppm にピークが出 現した。 また，重リン酸アルミニウム溶液では-15.3ppm のブロードな 1 本のピークが得られた。

いずれのバインダー溶液でも，パッチング材の硬化と ともに $\mathrm{Q}_{0}, \mathrm{Q}_{0}{ }^{\prime}$ 構造のみから $\mathrm{Q}_{1}, \mathrm{Q}_{1}{ }^{\prime}$ 構造が現れているの 

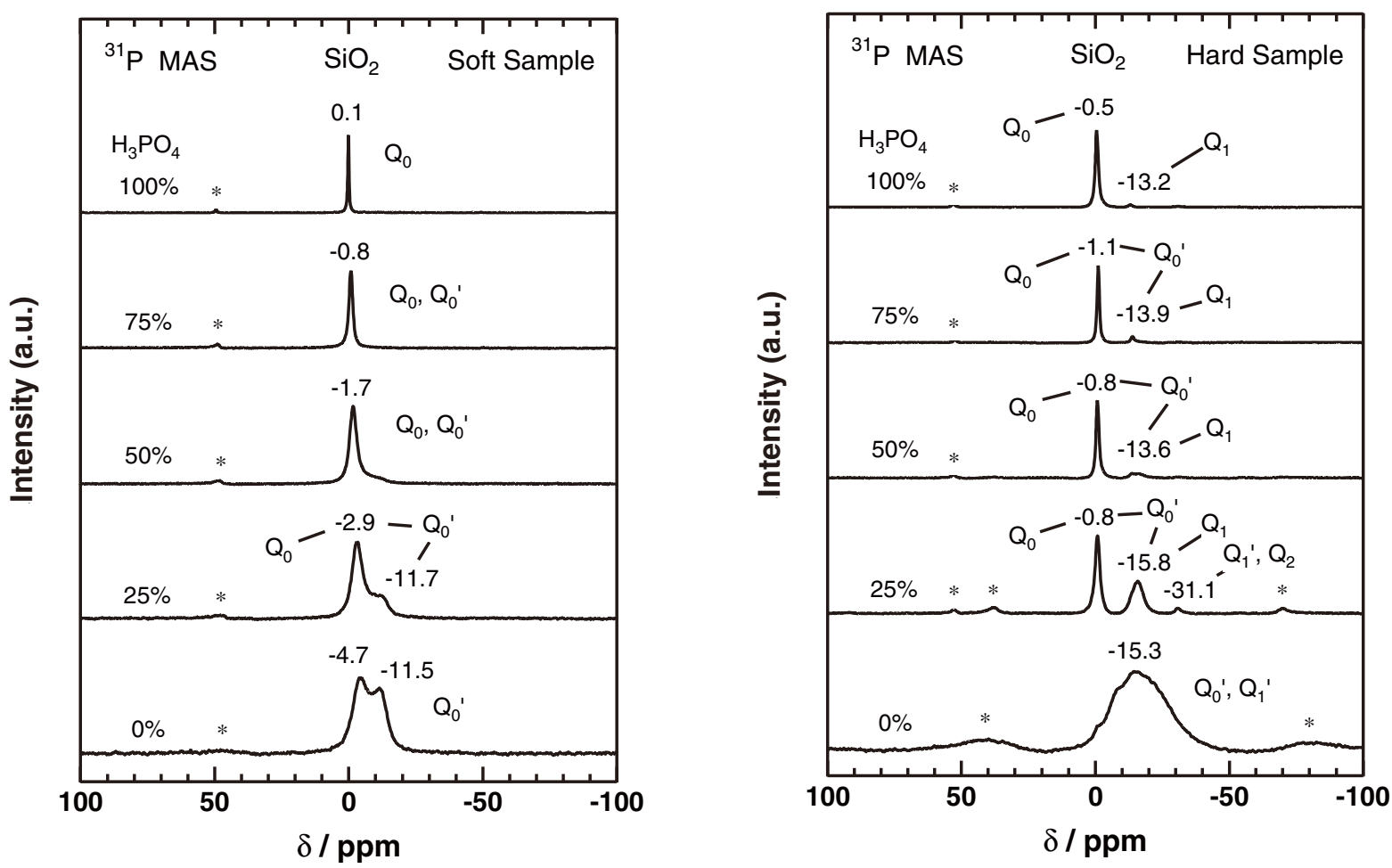

Fig. $3{ }^{31}$ P MAS NMR spectra of soft (left) and hard (right) refractory patching materials made by $\mathrm{SiO}_{2}$. Asterisks denote spinning side bands.

で，パッチング材が硬化するにつれて，架橋酸素をもつ リン原子の割合が増加していることが分かる。このこと は，パッチング材の硬化により脱水縮合が起こっている ことを示している。しかし硬化したパッチング材では， いずれもネットワーク形成能をもたない $\mathrm{Q}_{0}, \mathrm{Q}_{1}$ 構造ま

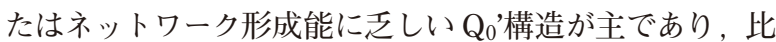
較的高いネットワーク形成能をもつ $\mathrm{Q}_{1}{ }^{\prime} ， \mathrm{Q}_{2}$ 構造は少数 であった。

Fig. 4 は電融アルミナ原料のパッチング材の ${ }^{31} \mathrm{P}$ MAS NMR スペクトルを示している。左図が柔らかい練り土 状のパッチング材，右図が完全に硬化したパッチング材 の ${ }^{31} \mathrm{P}$ MAS NMR スペクトルを示している.

左図のピークは $1.6 〜-11.7 \mathrm{ppm}$ の範囲で現れているの で，水分をいくらか含む柔らかい練り土状のパッチング

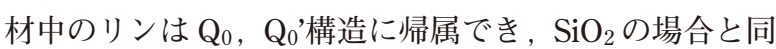
様にリン酸塩間の縮合は起こっていないと考えられる.

右図では，リン酸を 50 〜 100vol\% 含むバインダーで $-16 \mathrm{ppm}$ 付近の鋭いピークが現れた。リン酸を $25 \mathrm{vol} \%$ 含 むバインダーでは, $-15.9 \mathrm{ppm}$ と-21.3ppm にピークが出 現した。また，重リン酸アルミニウム溶液では-18.6ppm のブロードな 1 本のピークが得られた.

いずれのバインダー溶液でも, $\mathrm{SiO}_{2}$ の場合と同様にパッ

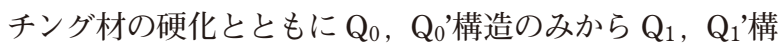
造が現れた。従って，パッチング材の硬化により，架橋 酸素をもつリン原子の割合が増加し, 脱水縮合が起こっ たと考えられる. 硬化したパッチング材のうち, リン酸を 0 ～ $25 \mathrm{vol} \%$ 含むバインダーでは， $\mathrm{Q}_{1}{ }^{\prime}$ 構造が増加してきて いるが，いずれもネットワーク形成能をもたない $\mathrm{Q}_{1}$ 構造 とネットワーク形成能に乏しい $\mathrm{Q}_{0}{ }^{3}$ 構造が主であった。

Fig. 3 と Fig. 4 の硬化した試料のスペクトル同士を比
較すると，リン酸を 25 ～100vol\% 含むバインダーでは， $\mathrm{SiO}_{2}$ 原料の硬化したパッチング材で見られた $0 \mathrm{ppm}$ 付近 の鋭いピークが, 電融アルミナ原料の硬化したパッチン グ材では消えていた。また， $\mathrm{Q}_{1} ， \mathrm{Q}_{1}{ }^{\prime}, \mathrm{Q}_{2}$ 構造に帰属で きる-13〜-31ppm のピーク強度は, 電融アルミナ原料 の方が， $\mathrm{SiO}_{2}$ 原料よりも高かった。 $\mathrm{Q}_{0}{ }^{\prime}, \mathrm{Q}_{1}$ 構造を含む 重リン酸アルミニウム溶液のピーク位置は, 電融アルミ ナ原料の方が， $\mathrm{SiO}_{2}$ 原料よりも高磁場側（右側）にあっ た。以上の結果より，同じバインダー溶液に打ける脱水 縮合したリン原子の割合は，電融アルミナ原料の方が $\mathrm{SiO}_{2}$ 原料よりも高いといえる。

\section{$3 \cdot 5$ パッチング材の作業性(可塑性)の低下機構}

パッチング材の ${ }^{31} \mathrm{P}$ MAS NMR 測定結果から，パッチ ング材の作業性（可塑性）の低下に伴う硬化によりリン 酸塩の一部が脱水縮合していることを明らかにした。し かし，パッチング材中のリン原子はいずれもネットワー クを形成しない $\mathrm{Q}_{0}, \mathrm{Q}_{1}$ 構造とネットワーク形成能に乏

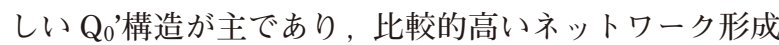
能をもつ $\mathrm{Q}_{1}{ }^{\prime}, \mathrm{Q}_{2}$ 構造は少数であった。つまり，脱水縮 合による-P-O-P-連結によって形成されるネットワーク の割合は小さいと考えられるので, リン酸塩の脱水縮合 によるネットワーク化のみで硬化するとは考えにくい.し かし実際には硬化している。これは，パッチング材の硬化 に影響を及ぼす別の原因が存在することを示唆している。

リン酸結晶 ${ }^{11)}$ は無水和物のとき無色の結晶であり, 非 常に吸湿性が強い.この結晶は $\mathrm{PO}_{4}$ 四面体の $\mathrm{OH}$ 基同士 がすべて水素結合で連結した層状構造を作っている。上 で述べたように, 無水の重リン酸アルミニウム結晶 ${ }^{5)} も$ $\mathrm{PO}_{4}$ 四面体と $\mathrm{AlO}_{6}$ 八面体とから成る直鎖間は $\mathrm{P}-\mathrm{OH}$ 基 間の水素結合で互いに連結した構造をしている。本研究 

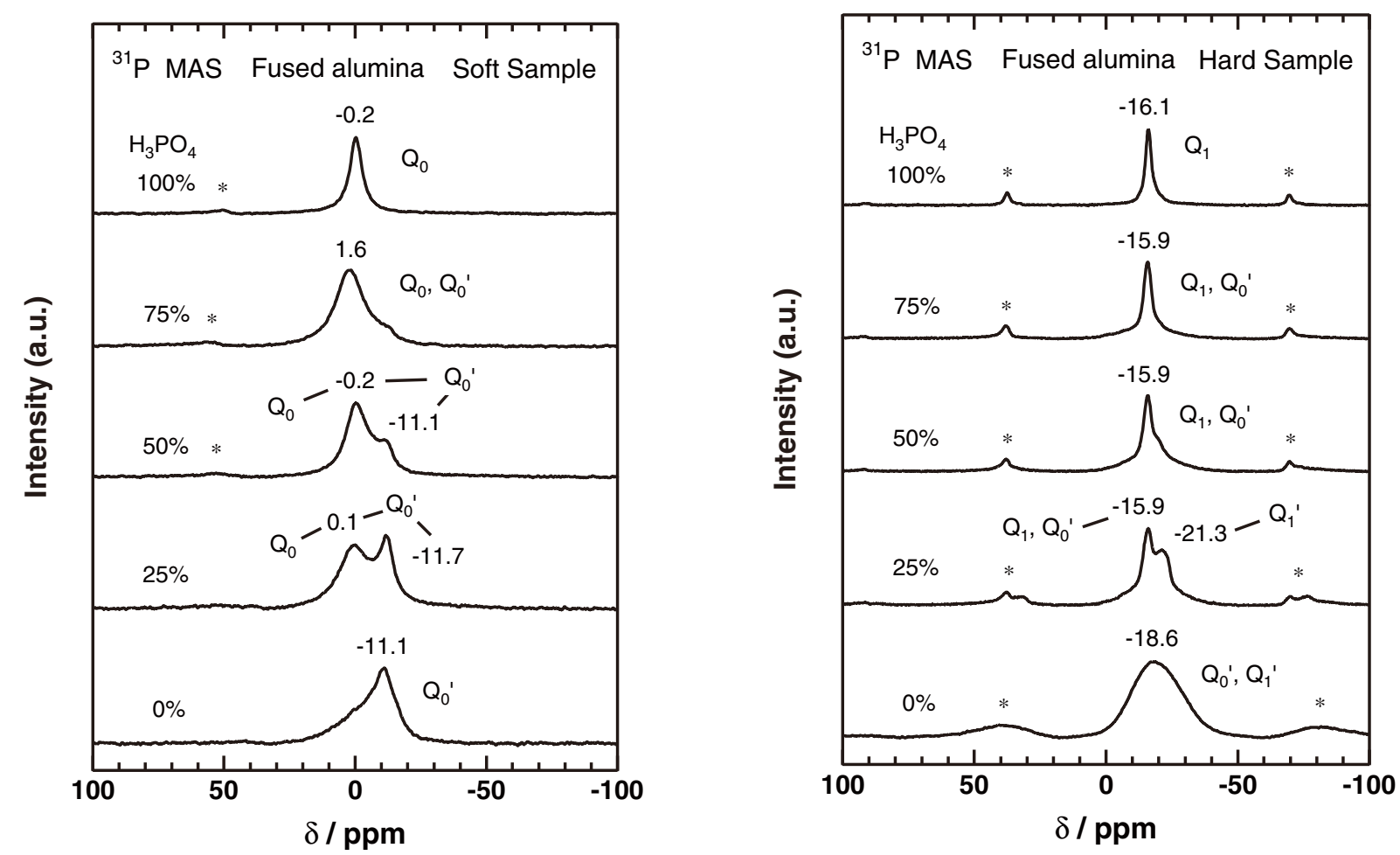

Fig. $4{ }^{31}$ P MAS NMR spectra of soft (left) and hard (right) refractory patching materials made by fused alumina. Asterisks denote spinning side bands.

におけるパッチング材は上記のリン酸（塩）を使用して いるので，無水状態では上の 2 つの結晶と類似の連結が 存在すると考えられる. 即ち，パッチング材中の水分の 蒸発に伴うリン酸 (塩) 同士の水素結合による連結が生 じると考えられる.

以上より，水分の減少によって引き起こされる水素結 合と脱水縮合が，パッチング材の作業性（可塑性）の低 下の原因と考えられる。

\section{4 結 論}

リン酸および重リン酸アルミニウム水溶液の混合溶液 から成るバインダー溶液, $\mathrm{SiO}_{2}$ および電融アルミナ粉末 とリン酸塩バインダーから作製したパッチング材の乾燥 前, 乾燥後の試料について ${ }^{31} \mathrm{P}$ 静止および MAS NMR 測定を行い，パッチング材中のリン原子の局所構造を明 らかにすることでパッチング材の作業性（可塑性）の低 下機構の解明を試みた結果, 次の結論を得た。

(1) 硬化後の試料は硬化前の試料に比べて脱水縮合し たリン原子の割合は多くなったが，ネットワークを作ら ない $\mathrm{Q}_{0}, \mathrm{Q}_{1}$ 構造とネットワーク形成能に乏しい $\mathrm{Q}_{0}{ }^{\prime}$ 構造 が主であり，比較的高いネットワーク形成能をもつ $\mathrm{Q}_{1}{ }^{\prime}$, $\mathrm{Q}_{2}$ 構造をもつリン原子は少数であった.

（2）同じバインダーを用いた場合，原料の種類によっ て脱水縮合したリン原子の割合が変化し, 電融アルミナ 材質の方が $\mathrm{SiO}_{2}$ 材質よりも脱水縮合したリン原子の割合 が多かった

（3） パッチング材の作業性（可塑性）の低下の原因 は，水分の減少によって引き起こされる水素結合による リン酸塩間の連結ならびにリン酸 (塩) 同士の脱水縮合 によるネットワークの形成と考えられる。

\section{参 考 文 献}

1) Haikibutsugakkai-Hen, "Haikibutsu handbook", pp.157-158 (1997) Ohmsha, Japan.

2 ) The Ceramic Society of Japan, "Handbook of ceramics" 2nd Edition, Ohyou, pp.844-846 (2002) Gihodoshuppan, Japan.

3 ) T. Taniguchi, "Aluminium phosphate bonded refractory specialities”, Ceramics Japan, Vol.1, No.2, pp.66-71 (1966).

4 ) S. Nagahama and S. Yamamoto, "Aluminum-phosphate binders for refractories”, Taikabutu, Vol.29, No.8, pp.412-425 (1977).

5 ) The Ceramic Society of Japan, "Handbook of ceramics" 2nd Edition, Ohyou, pp.44-47 (2002) Gihodoshuppan, Japan.

6 ) The Ceramic Society of Japan, "Handbook of ceramics" 2nd Edition, Ohyou, pp.784-788 (2002) Gihodoshuppan, Japan.

7 ) R. Kniep and M. Steffen, "Aluminium-tris (dihydrogenphosphat)", Angewandte Chemie, Vol.90, No.4, p.286 (1978).

$8)$ M. W. G. Lockyer, D. Holland, A. P. Howes and R. Dupree, "Magic-angle spinning nuclear magnetic resonance study of the structure of some $\mathrm{PbO}-\mathrm{Al}_{2} \mathrm{O}_{3}-\mathrm{P}_{2} \mathrm{O}_{5}$ glasses", Solid State Nuclear Magnetic Resonance, Vol.5, pp.23-34 (1995).

$9)$ R. K. Brow, R. J. Kirkpatrick and G. L. Turner, "Local structure of $\mathrm{xAl}_{2} \mathrm{O}_{3} \cdot(1-\mathrm{x}) \mathrm{NaPO}_{3}$ glasses : an NMR and XPS study", Journal of the American Ceramic Society, Vol.73, No.8, pp.2293-2300 (1990).

10) I. L. Mudrakovskii, V. P. Shmachkova, N. S. Kotsarenko and V. M. Mastikhin, " ${ }^{1}$ P NMR study of I-IV group polycrystalline phosphates", Journal of the Physics and Chemistry of Solids, Vol.47, No.4, pp.335-339 (1986).

11) M. Nakahara, "Mukikagoubutu · sakutaiziten”, pp.1056-1057 (1997) Koudansyasaienthifiku, Japan. 